\title{
Social provisioning for mine closure
}

\author{
T Laurencont Coffey Mining Pty Ltd, Australia \\ T Garrood Newcrest Mining Limited, Australia \\ P Vidler Coffey Mining Pty Ltd, Australia \\ M Fawcett Coffey Mining Pty Ltd, Australia
}

Note: this paper is a late inclusion to the Proceedings of the 13th International Conference on Mine Closure and hence does not appear in the printed proceedings or include page numbers.

\begin{abstract}
Guidance on closure planning is still very much focused on the biophysical rather than the socio-economic aspects of closing a mine. Although on face value, the biophysical and social domains can be categorised in a similar way, their context can often be broader and would be better considered to be an episode in the ebb and flow of life in the surrounding communities (Bainton \& Holcombe 2018).

Social closure planning must deal with a high level of complexity, stemming from the fact that the social environment is generally in a state of continual flux over the life of a project, and is subject to development support interventions both from the government and the project. These support interventions should have regard to a target social closure outcome that has been discussed and agreed with landowner communities and other relevant stakeholders.
\end{abstract}

Newcrest Mining Limited (Newcrest) became a member company of the International Council on Mining and Metals (ICMM) in November 2017. The ICMM is a mining industry organisation. Admission to the ICMM requires member companies to commit to ICMM's Sustainability Framework (ICMM 2015), its position statements, and its assurance process (whereby a third-party audits a companies' sustainability performance).

At a company level, Newcrest has developed a number of environmental and social standards including a specific closure standard. Newcrest's Mine Closure Management Guideline has been developed to assist sites in understanding how to apply these standards. This translates at a site-specific level to operational closure plans and costing estimates for the closure of operating sites.

In this context, Newcrest set out to identify what represents good practice in terms of social closure, so that their standards and guidelines can reflect this, especially in relation to developing a consistent methodology for the calculation of social closure costs.

This paper explores that journey, from understanding what is current industry good practice in relation to social closure aspects, how to develop socio-economic closure domains and the process of costing (social provisioning) once the closure domains have been decided is discussed.

\section{Introduction}

Newcrest Mining Limited (Newcrest) is one of the world's largest gold mining companies who believe in operating and developing mines sustainably in line with their sustainability and environmental policies and standards and building lasting relationships with the communities in which they operate. NML's vision is 'to be the miner of choice for our people, shareholders, host communities, partners and suppliers'.

In support of this vision, Newcrest became a member company of the International Council on Mining and Metals (ICMM) in November 2017. ICMM has identified mine closure to be one of the focus areas in ensuring that the mining and metals industry contributes to sustainable development. The ICMM believes that mine 
closure should be a core component of mine planning though integration of closure planning from the design phase of an operation and throughout the life-of-mine.

ICMM guidance outlines that a thorough understanding of the closure methodology will reduce the risk component of the closure cost estimate and enable adequate financial provisions to be established by mine operators. This is linked to the need for a clearly defined process for development of a closure plan and for the operator to have adequate technical and financial resources for future reviews and updates to the closure plan.

In support of the Sustainable Development Goals, the ICMM provides guidance information on supporting social and economic development so as to facilitate the development and eventual closure of mines in a socially and environmentally responsible manner. This includes information on supporting local economic growth and poverty alleviation through partnerships, regional development and local sourcing of labour, materials, goods and services. These social and economic aspects are considered important considerations in closure planning.

However, this guidance still remains very much focused on the biophysical rather than the socio-economic aspects of closing a mine. Although on face value, the biophysical and social domains can be categorised in a similar way, their context can often be broader and would be better considered to be an episode in the ebb and flow of life in the surrounding communities (Bainton \& Holcombe 2018). Social closure planning must deal with a high level of complexity, stemming from the fact that the social environment is generally in a state of continual flux over the life of a project, and is subject to development support interventions both from the government and the project. These support interventions should have regard to a target social closure outcome that has been discussed and agreed with landowner communities and other relevant stakeholders.

In this context, Newcrest set out to identify what represents good practice in terms of social closure, so that their standards and guidelines could reflect this, especially in developing a consistent methodology for the calculation of social closure costs.

This paper explores that journey, from the development of an understanding of industry good practice in relation to social closure aspects, to the establishment of how to develop socio-economic closure domains. Finally, the process of costing (social provisioning), once the closure domains have been decided is discussed.

\section{$2 \quad$ Benchmarking}

\subsection{External guidance}

\subsubsection{ICMM}

ICMM is a mining industry organisation. Admission to ICMM requires member companies to commit to ICMM's Sustainability Framework (ICMM 2015), its position statements, and its assurance process (whereby a third-party audits companies' sustainability performance).

ICMM has identified mine closure to be one of the focus areas in ensuring that the mining and metals industry contributes to sustainable development. The ICMM believes that mine closure should be a core component of mine planning though integration of closure planning into the design phase of an operation. To support this, the ICMM released a good practice guide entitled Integrated Mine Closure (hereafter, ICMM toolkit) (ICMM, 2019).

Planning and preparation for social transition to help reduce the negative impacts of social change for the workforce and communities connected to the mine site and improve the legacy of benefits from mining activities are featured in the ICMM good practice guide. Of the tools in the good practice guide, those relating to social aspects include: 
- Tool 9: Consideration in developing closure activities for transversal issues - which details for consideration in developing social transition activities.

- Tool 5: Key Messages for social transition - which provides a collection of example key messages that are appropriate for each stage of the mining life cycle leading up to the implementation of final closure.

- Tool 6: Social transition activities checklist - which provides a checklist of activities that will assist planning for social transition from the early stages of design and permitting through to closure.

The ICMM has released a report, 'Financial Assurance for Mine Closure and Reclamation' (2005), with an accompanying guidance paper (ICMM, 2006). Financial assurance is recognised as necessary for metals and minerals to be produced in a socially acceptable manner. However, closure costs and calculations for financial assurance that are based on closure cost estimates are both substantial and subject to high degrees of uncertainty. Three issues are articulated in the guidance paper:

1. Unclear closure standard - What is an 'acceptable' standard of closure is often unclear, leaving companies uncertain what degree of liability they carry post-closure.

2. Wide variation in methods for calculating closure costs.

3. Cost-effectiveness and policy flexibility - Whether policy should account for track record of the company to lower assurance amounts and if so, how.

In general, the report states that a thorough understanding of the closure methodology will reduce the risk component of the closure cost estimate (see also Tool 10, 'Cost risk assessment for closure'). For sites that have a conceptual understanding of closure and limited information, the risk of failing to meet closure standards (however defined) will be high and will be reflected in a conservative estimate of cost. As the level of information on closure increases, the accuracy of the estimate will increase, reducing the risk and the potential overestimation of the closure cost. Closure costs should also include all activities required to close the site and include annual post-closure expenditures that may be necessary. In some cases, this may be needed for years or decades.

The guidance paper identifies that the operator should be able to establish adequate financial provisions for closure and reclamation. It should include:

- A defined post-closure land use.

- A good understanding of the site baseline conditions and clear definitions of the zone of influence and key receptors.

- Input from key stakeholders.

- Consideration of potential social impacts and benefits associated with environmental quality and potential future land use alternatives.

- Use of risk analysis methods in the plan development and to establish the design criteria, for example to address the possibility of major events (e.g. earthquake, flooding).

- A clearly identified sequence and schedule of closure activities.

- The application of, where possible, progressive rehabilitation of areas during the operating life of the mine.

- Schedule of regular reviews and adjustments of the plan and after changes in operations or conditions.

- Closure cost calculations which are consistent and transparent, and based on reasonable estimate of actual costs taking into account local conditions and cost structures. 
In support of the Sustainable Development Goals, the ICMM provides significant guidance information on supporting social and economic development to facilitate the development and eventual closure of mines in a socially and environmentally responsible manner. This includes information on supporting local economic growth and poverty alleviation through partnerships, regional development and local sourcing of labour, materials, goods and services. These social and economic aspects are considered important considerations in closure planning. However, there is currently no specific requirement to cost them as part of the financial assurance.

\subsubsection{International Financial Corporation}

The International Finance Corporation's Performance Standards on Environmental and Social Sustainability (IFC 2012) applies to projects funded by the IFC. However, the Performance Standards are often used as a benchmark by non-IFC projects.

The Performance Standards comprise eight standards that govern all potential IFC projects. It does not specifically address mining, nor focus on closure - although Performance Standard 1 (Assessment and Management of Environmental and Social Risks and Impacts) expressly applies to activities from the early developmental stages through the entire lifecycle (design, construction, commissioning, operation, decommissioning, closure or, where applicable, post-closure).

The IFC has also released 'Environmental, Health, and Safety Guidelines' for the mining industry (IFC 2007). Section 1.4 of the guidelines addresses mine closure and post-closure, stating that mine closure plans should be designed so that 'adverse socio-economic impacts are minimised and socio-economic benefits are maximised'.

\subsection{Regulatory requirements}

\subsubsection{Western Australia}

The Department of Mines, Industry Regulation and Safety (DMIRS) is the lead regulator and decision-making authority for mining projects in Western Australia (WA) under the Mining Act 1978 (the Mining Act). This includes regulating the mining industry to ensure closure commitments made are implemented during the life of the mining project. The Environmental Protection Agency (EPA) is a statutory authority established with the current Department of Environment and Water Resources pursuant to the Environmental Protection Act 1986 (the EP Act). When a mining proposal is considered to be significant it will be assessed by the EPA under Part IV of the EP Act. The EPA formally assesses mine closure under Part IV of the EP Act, where mining projects are not subject to the Mining Act such as:

- Pre-1989 title or minerals-to-owner tenure,

- Hampton locations or certain State Agreement Act projects, or

where the EPA considers that there is a significant impact or risk and identifies rehabilitation and closure as a preliminary Key Integrating Factor of a proposal as defined in the EP Act.

The Guidelines for Preparing Mine Closure Plans (DMIRS 2015) (the Guidelines) provide specific guidance on the preparation of mine closure plans to meet WA regulatory requirements. These guidelines are approved by the Director-General of Mines under section 700 of the Mining Act and are approved by the EPA.

Principle 5 of the Guidelines identifies that where practical, communities should be worked with to manage the potential impacts of mine closure and that DMP and EPA encourages regular engagement between mining companies and local communities throughout all stages of mine development. To manage potential socio-economic and environmental impacts of mine closure, development of community programs should be aimed at strengthening the community over time.

The Guidelines detail what financial provisioning for a site should include and are listed here, including:

- Earthmoving and landscape forming. 
- Management of problematic materials where relevant.

- Post-closure management of surface water drainage.

- Closure research and trials.

- Decommissioning and removal of infrastructure.

- Remediation of contamination.

- Progressive and final rehabilitation.

- Maintenance, and monitoring and auditing programs including post-closure phase.

- Ongoing stakeholder engagement processes.

- Closure project management costs.

- Specialist and consultant fees.

- Legal requirements.

- Provision for premature closure (permanent closure or suspended operations under care and maintenance).

- Provision for installing additional infrastructure if required for the agreed land uses.

- Provision for potential delays, extreme events or other external factors relevant to closure.

\subsubsection{New South Wales, Australia}

In New South Wales (NSW), both the Department of Planning and Environment (DPE) and the Division of Resources and Geoscience (DRG) play key roles in mining regulation. Applications for mining are assessed under the Environmental Planning and Assessment Act 1979. The acceptability of the proposal and outcomes are considered by both DPE and the consent authority (generally the independent Planning Assessment Commission). If the application is approved, rehabilitation outcomes are incorporated into the conditions of the development consent. A mining lease issued by DRG under the Mining Act 1992 is also required. A key component of this regulatory framework is the requirement for the holder of the mining lease to lodge a rehabilitation security deposit with DRG. The amount of the security deposit is detailed in the Rehabilitation Cost Estimate (RCE). The RCE is based on the rehabilitation works developed as part of the mining operations plan (MOP) for the site. This plan is approved by DRG.

The ESG3: Mining Operations Plan (MOP) Guidelines (NSW Trade \& Investment 2013) list the primary (operational) and secondary (post-mining land use) domains which should be considered as part of rehabilitation planning and management. All of the listed closure domains are biophysical, with no social or economic domains listed. The ESG1: Rehabilitation Cost Estimate Guidelines (NSW Department of Planning and Environment 2012) and Rehabilitation Cost Estimation Tool Handbook (NSW 2017) detail how to prepare a RCE and are focused on costing infrastructure, landforms, underground infrastructure, dams, exploration operations, environmental monitoring and project management.

\subsubsection{Northern Territory, Australia}

Mining activities in the Northern Territory are administered by the Mining Management Act and the Mineral Titles Act. The Mineral Titles Act establishes a framework for granting and regulating of mineral titles that authorise exploration for, and extraction and processing of, minerals and extractive minerals in the Northern Territory. The Mining Management Act is administered by the Northern Territory Department of Primary Industry and Resources (the Department) and contains the framework for managing mining activities including rehabilitation and a plan and costing of closure activities through information detailed within a Mining Management Plan prepared by the mining operator. 
Financial assurance (referred to as security) is required as a condition of the Authorisation to undertake mining activities (the Authorisation). The purpose of this security is to secure the operator's obligation to comply with the Act and the requirements of the Authorisation, the payment of costs and expenses in relation to the relevant Minister taking an action to prevent, minimise or rectify environmental harm caused by mining activities and the payment of costs and expenses in relation to the relevant Minister taking an action to complete rehabilitation of the mining site.

The Minister may impose conditions on an Authorisation in relation to the provision of social and economic benefits to communities outside the mining site that will be directly affected by the mining activities to be carried out. In addition, Community Benefit Programs (i.e. programs which support local health and wellbeing or social activities or infrastructure) can also be required as part of Mining Agreements negotiated between relevant stakeholders and the mining operator. Both Glencore's MacArthur River Mining Operations and Newmont Tanami's Gold Operations have supported the development of their respective local indigenous communities through the implementation of Community Benefit Programs. However, there is currently no formal requirement to include these types of activities or programs as part of the security.

\subsubsection{Papua New Guinea}

The principal regulatory instrument governing mine closure in Papua New Guinea (PNG) is the Mining Act 1992, which is administered by the Mineral Resources Authority (MRA), with authority vested by section 5 of the Mineral Resources Authority Act 2005. The Environment Act 2000 is also a source of obligations for mining companies, whether directly under the statute or indirectly as a condition of approvals governed by statue.

The Mining Act does not directly provide for mine closure or mine rehabilitation. It is largely procedural legislation - it contains provisions establishing certain administrative bodies (such as the Mining Advisory Board: s 11), setting out the types of licences and tenements that can be applied for, and the processes by which such interests are considered and granted. While the grant of a licence or tenement (under the Mining Act) can include conditions relating to mine closure, there is no legislative direction on mine closure.

The PNG Mining Policy is available on the MRA website, marked as a draft and dated 2012, with no subsequent version apparently available. Part 20 of this policy requires mine developers to submit a 'Conceptual Mine Closure Plan' when applying for a mining lease. This plan must include, alongside other plans, a 'Social Mitigation Plan' and 'Consultation mechanisms with stakeholders'

The Environment Act 2000 is administered by the Conservation and Environment Protection Authority (CEPA), formerly the Department of Environment and Conservation. Mining operations require an environment permit, which would generally require an environmental impact assessment under section 51 .

The Environment Act does not provide substantive obligations in relation to mine closure. The PNG National Executive Council may, on the Environment Minister's recommendation, make an Environment Policy under section 30, which may provide for 'decommissioning and rehabilitation requirements' under section 31.

The Act also empowers the Director of Environment (the officer in charge of CEPA) to require a person carrying out an activity likely to result in a change to the environment, or a person operating under an environment permit, to 'lodge with the Director an environmental bond supported by a bank guarantee, insurance policy or other security approved by the Director' (s 99). The purposes for which such a bond may be required is not specified.

\subsubsection{South Africa}

Mining activities in South Africa are administered by the Minerals and Petroleum Resources Development Act (MPRDA) which establishes a framework for administering tenure in respect of prospecting, exploration, mining and production operations. Environmental management principles are established in the National Environmental Management Act 1998 and are applicable to all prospecting and mining activities. These serve as guidelines for the interpretation, administration, and implementation of the environmental requirements of the MPRDA. Financial assurance (referred to as a financial provision) for environmental rehabilitation and 
closure is administered under the MPRDA and is also detailed within the Department of Environmental Affairs National Environmental Management Act (No.107 of 1998 Regulations Pertaining to the Financial Provisions for Prospecting, Exploration, Mining or Production Operations (the Regulation). Financial provisions are administered by the Department of Mineral Resources Republic of South Africa (the Department).

The financial provision will include a detailed itemisation of all activities and costs, calculated based on the actual costs of implementation of the measures required for:

- Annual rehabilitation, as reflected in an annual rehabilitation plan.

- Final rehabilitation, decommissioning and closure of the prospecting, exploration, mining or production operations at the end of the life of operations, as reflected in a final rehabilitation, decommissioning and mine closure plan.

- Remediation of latent or residual environmental impacts which may become known in the future, including the pumping and treatment of polluted or extraneous water, as reflected in an environmental risk assessment report.

As part of an application for mining rights the applicant is required to submit a social and labour plan (SLP) to the Department. The MPRDA regulations detail what a SLP must contain, this includes:

- Local economic development program:

- The social and economic conditions in the area in which the mine operates and communities where workers are recruited.

- The main economic activities of the area in which the mine operates and in communities where workers are recruited (such as agriculture, tourism or food processing).

- The impact that the mine would have on communities living near to the mine and communities where workers are recruited (e.g. the possibility that people will need to relocate, the number of people that may arrive in the area).

- Infrastructure and poverty eradication projects that the mine would support.

- The measures to address the housing, living conditions and nutrition of the mine workers.

- The mine's plan to meet targets for procuring goods and services from historically disadvantaged South African companies.

- Human resources development program:

- A skills development plan for the workforce.

- A career progression plan which is a plan to ensure workers are able to progress to more senior positions.

- A mentorship plan.

- The employment equity statistics of the mine, as well as the mine's plan to ensure that $10 \%$ of the workforce are women and $40 \%$ of management positions are occupied by disadvantaged South Africans within 5 years of mining commencing.

- Managing downscaling and retrenchment:

- Plans to save jobs and avoid job losses and a decline in employment.

- Plans to provide alternative solutions and procedures for creating job security where job losses cannot be avoided.

- Plans to minimise the social and economic impact on individuals, regions and local economies where retrenchment and closure of the mine is certain.

The programs detailed in the SLP must be budgeted for and included in the financial provision for the site. 
New National Environmental Management Act legislation (GN R 1228) will require all mines to develop plans and costs for final rehabilitation, decommissioning and closure (unscheduled), post-closure residual impacts supported by an environmental risk assessment and annual rehabilitation costs.

\section{What constitutes good industry practice}

The previous sections of this paper have described how the social aspects of closure are addressed by both regulatory and industry bodies. Most of this information focuses on what should be included in the planning process, with limited specific information on how it should be implemented, providing flexibility for implementation by operators.

The regulatory frameworks assessed tended to focus more on the biophysical aspects of closure. However, South Africa requires the development of an SLP which includes a local economic development program, human resources development program and managing downscaling and retrenchment. The programs detailed in the SLP must be budgeted for and included in the financial provision for the site. The SLP looks at a 5 year period.

Several common features, or good practice measures for social closure planning were evident in the documentation reviewed, however less well described were some of the challenges that need to be addressed to meet these measures, particularly in regions that have a limited engagement with a market economy. These measures are listed in Table 1.

Table 1 Good practice measures and challenges in meeting them (continued next page)

\begin{tabular}{|c|c|}
\hline Good practice measure & Challenges \\
\hline \multirow{3}{*}{$\begin{array}{l}\text { Measurable closure outcomes informed } \\
\text { by effective stakeholder engagement }\end{array}$} & Ability to manage competing interests. \\
\hline & $\begin{array}{l}\text { Stimulating interest in engagement regarding an event that } \\
\text { may be a couple of generations in the future. }\end{array}$ \\
\hline & $\begin{array}{l}\text { Stakeholders who regard engagement as an avenue to } \\
\text { leverage resources over those defined in a mining } \\
\text { agreement. }\end{array}$ \\
\hline \multirow[t]{2}{*}{$\begin{array}{l}\text { The setting of closure outcomes very } \\
\text { early in the project life and then refined } \\
\text { as necessary }\end{array}$} & $\begin{array}{l}\text { Socio-economic systems that are in flux and at the periphery } \\
\text { of a market economy, where viable economic options are } \\
\text { limited. }\end{array}$ \\
\hline & $\begin{array}{l}\text { Establishing an agreed vision of socio-economic functioning } \\
\text { at the end of a mine. }\end{array}$ \\
\hline \multirow{2}{*}{$\begin{array}{l}\text { Closure planning is informed by a well- } \\
\text { developed knowledge of the status and } \\
\text { functioning of the socio-economic } \\
\text { system }\end{array}$} & $\begin{array}{l}\text { Developing an understanding of the dynamic nature of the } \\
\text { socio-economic system, rather than a snapshot of status at a } \\
\text { point in time. }\end{array}$ \\
\hline & $\begin{array}{l}\text { Commitment to ongoing capture, analysis and consideration } \\
\text { of socio-economic data. }\end{array}$ \\
\hline \multirow[t]{2}{*}{$\begin{array}{l}\text { Closure planning is undertaken as a } \\
\text { multi-disciplinary endeavour }\end{array}$} & $\begin{array}{l}\text { Limited in-house capability to assess and influence socio- } \\
\text { economic development strategies. }\end{array}$ \\
\hline & $\begin{array}{l}\text { Focus is on resolving immediate issues and grievances with } \\
\text { little time left to focus on supporting long-term socio- } \\
\text { economic development. }\end{array}$ \\
\hline
\end{tabular}




\begin{tabular}{ll}
\hline Good practice measure & Challenges \\
\hline $\begin{array}{l}\text { Community support measures support } \\
\text { socio-economic system development and } \\
\text { transition to a state that is defined in } \\
\text { Mining Agreements }\end{array}$ & $\begin{array}{l}\text { Limited ability to influence the actions of landowners or } \\
\text { government in the implementation of a long-term } \\
\text { development model. } \\
\text { Agreements that govern resources flows to various parties } \\
\text { but that aren't aligned to a development plan outlining a } \\
\text { strategic development pathway for a region or locality. }\end{array}$ \\
$\begin{array}{l}\text { Social closure outcomes are assessed } \\
\text { (and revised or fine-tuned) at each } \\
\text { revision of the mine plan }\end{array}$ & Having defined and measurable social closure outcomes. \\
\hline
\end{tabular}

Throughout the life of a mining operation local communities will become directly and indirectly dependent on the mining activities. As such integrating the social aspects of a site into the closure domains (supported with the development of closure objectives and criteria) is critical to the overall success of the closure process. This will also allow for the costing of these social aspects.

In order to develop site-specific social domains, the following is required:

- Comprehensive stakeholder engagement.

- Comprehensive knowledge base.

- Development of a realistic post-mining vision (that includes post-mining land use).

- Assessment of community viability post-closure.

For closure, achieving a good standard of social performance would require:

Informed communities, possessing a vision for a desired post-mining socio-economic environment, with an identified pathway and support for the required socio-economic transition to that environment (Vidler pers comm, 2019).

Implementing good mine closure practice would also require a closure approach supported by communities, government, the business sector and civil society.

\section{$4 \quad$ Proposed approach to planning for social closure aspects}

The social aspects of closure requires a clearly structured approach to planning and consideration of the current functioning of the local and regional socio-economic system, and its functioning in a post-mine environment. Consideration needs to be given to a four-stage approach, outlined below in Table 2 .

Table 2 Four-stage approach (continued next page)

\begin{tabular}{ll}
\hline Stage & Approach \\
\hline $\begin{array}{l}\text { Establishing the baseline socio- } \\
\text { economic conceptual model }\end{array}$ & $\begin{array}{l}\text { Define community catchment areas, the current level of socio- } \\
\text { economic development within those areas, and the linkages and } \\
\text { resource flows (and their significance) between the mining } \\
\text { operation and the local/regional/national economy }\end{array}$ \\
$\begin{array}{ll}\text { Confirm community socio-economic } \\
\text { aspirations to inform planning }\end{array}$ & $\begin{array}{l}\text { Consult to confirm the understanding of where the community } \\
\text { aspires the level of socio-economic development to be by when. } \\
\text { If there is a formal development plan, assess its currency and } \\
\text { legitimacy; if no formal plan, situate community aspirations } \\
\text { within a planning framework. }\end{array}$ \\
&
\end{tabular}


Undertake an assessment of the effects of mine closure

Develop a closure social support program
Assess what will be the effects of removing mine-stimulated resource flows on the current socio-economic system and the achievement of development plans. Will current minesupported social and economic support programs be an enabler or a barrier to community achievement of socio-economic goals?

Determine what options are available, in the period prior to closure, to remove barriers to, or to be an enabler of, the achievement of socio-economic objectives. This will include use of assets (principally land and infrastructure) within mine tenement boundaries.

To cost the socio-economic aspects of closure, domains should be developed, which can then be linked to closure objectives and criteria. The following domains have been developed to support this type of framework and to allow for inclusion within a provisioning calculator. However, it should be noted that the specific matters to be considered will be site-specific, and dependent on an agreed social closure plan that includes a robust conceptual socio-economic model of the mine's role and significance in the local and regional economy. Sites may be aware of other matters that are unique to their situation and these should be included in the calculator.

\subsection{Social baseline}

This is the first step that must be undertaken to fully account for the social impacts of closure and ensure that it correctly planned for. Matters to be considered and costed where necessary include; a social baseline study and a closure impacts study. These studies are intended to determine community socio-economic aspirations which can then inform closure planning.

\subsubsection{Socio-economic model development and baseline study}

Define community catchment areas, the current level of socio-economic development within those areas, and the linkages and resource flows (and their significance) between the mining operation and the local, regional and national economy. Ideally, the mining operation will have established a model during the operational phase. If that is the case, the baseline study may involve reviewing the model components, and be in the nature of re-baselining key parameters.

\subsubsection{Closure impacts studies}

The purpose of these types of studies is to assess what will be the effects of mine closure and removal of any resource flows based on the mine's presence. These need to be considered at local, regional and national levels. Will current mine-supported social and economic support programs be an enabler or a barrier to community achievement of socio-economic goals post-closure, with the cessation of resource flows (due to employee wages, royalty payments, government taxes, procurement through local businesses etc.)?

\subsection{Consultation}

Effective consultation is critical to closure planning, as it will inform how the transition from the operational phase through to the closure phase occurs with the least impact on the community and all levels of government.

\subsubsection{Community}

Consultation with the community will likely involve more than simply conducting meetings. Other costs that must be accounted for will include: 
- Funding community liaison positions.

- Engagement of specialist consultants.

- Costs associated with holding meetings, which may include travel, catering and accommodation.

- Travel for community representatives - visiting other operations and closed sites.

- Publications and documentation and other communication costs (advertising etc.).

\subsubsection{Government (local and national)}

Potential costs in this area could include:

- Travel for meetings.

- Production of documentation.

\subsubsection{Non-Government organisations}

Often it will be warranted to consult with non-government organisations (NGOs) who are active in supporting community development in mine-impacted communities. Where this occurs, costs may be similar to the categories for the other groups.

\subsection{Trust fund}

If a trust fund is selected as the vehicle to provide post-closure financial support to communities, then allowances will need to be made for:

- Contributions.

- Setup costs.

- Training in administration of the fund and governance structures.

\subsection{Local community}

The list of examples provided in this section is not intended to be exhaustive, however it does cover the most likely areas to be common across most operations. Sites should identify their own specific issues and cost them. All communities need skills, as well as access to resources, that enable them to pursue viable livelihoods consistent with their aspirations for individual and family wellbeing. This will include skills that allow mine employees to pursue alternative livelihoods (such as more advanced skills in agricultural production and marketing), as well as enhanced technical skills that may support ongoing employment in the mining industry at other locations (as this may be more effective in maintaining resource flows through wages entering the local economy).

\subsubsection{Skills audit}

Undertake an audit of the skills base of the local community to inform how the community may be able to participate in post-closure site activities. These activities may include small business, providing monitoring and maintenance of the closed site, operating and maintaining infrastructure transferred to the community.

\subsubsection{Training}

Where the skills audit identifies that training is required, then structured programs must be developed and delivered. The following are provided primarily as examples and can be deleted or expanded depending on the site's particular conditions. 


\subsubsection{General farming}

Provision of training to raise the local community's skill levels with respect to increasing production levels (crop yields, animal husbandry, forestry, aquaculture), diversification and sustainable farming practices.

\subsubsection{Business governance}

Training to ensure that communities have the appropriate levels of understanding of business governance to enable them to run sustainable business. This may be as simple as understanding basic banking and accounting through to business regulation and reporting requirements.

\subsubsection{Apprenticeships}

Technical skills will generally be needed in a community to support a viable post-mining economy. Some of these skills may be a legacy of mine employment (e.g. electrical and mechanical skills to maintain community power supplies or agricultural processing machinery), while others may be new (e.g. refrigeration mechanics to support agricultural produce storage infrastructure). Skill levels required would also need to be assessed, as full apprentice training may not be warranted.

\subsubsection{Education support}

Ongoing investment in human capital development through education support will generally be essential to a community's long-term future. This may take several forms, such as ensuring financial capability for school facility development and maintenance, support for teacher professional development and retention, or support for individuals through a scholarship fund. The specific measures will be subject to consultation and negotiation with community stakeholders.

\subsubsection{Tourism}

Funding to facilitate tourism developments in the local area, these may focus on the former mining operation, local features or culture.

\subsection{Infrastructure}

The management of infrastructure leading up to closure, and subsequent ownership and management postclosure, is potentially a major area contributor to community impact, either positive or negative, depending on how it is planned, communicated and managed.

Poor planning and communication can leave communities and governments with ongoing liabilities they are either unable to manage, either from a skills or financial perspective.

\subsubsection{Audit}

Undertake a comprehensive audit of all infrastructure associated with the operation. This audit will include:

- Type of infrastructure.

- Condition of infrastructure.

- Purpose and suitability for retention post-closure.

- Regular maintenance requirements including cost.

- Skill levels required to operate and/or maintain.

\subsubsection{Re-purposing infrastructure}

Identifying infrastructure that can be repurposed for the benefit of the local community or regional or national government. Examples of this may include: 
- Borefields - minor reconfiguration may enable them to supply local communities or agricultural enterprises.

- Power stations and distribution networks.

- Telecommunications.

- Buildings.

- Airfields.

- Ports.

- Equipment and vehicles.

\subsubsection{New infrastructure}

New infrastructure may be warranted for the benefit of the community or region. When this occurs, it must be appropriate and affordable to sustain in the long-term. Appropriate funding and/or management agreements must be in place to support the infrastructure, as would also be the case with repurposed infrastructure.

As with all other areas of social provisioning, the specifics will be site dependent, however examples may include:

- Additional roads.

- Mini hydroelectric plants.

- Power and water distribution.

\subsubsection{Infrastructure maintenance}

Following on from the infrastructure audit it may be necessary to undertake an upgrade program on any infrastructure that has been identified to be handed over to ensure that it is fit for purpose, and in a fully operational condition at the time of handover.

\subsubsection{Infrastructure maintenance training}

For any infrastructure that is handed over it will be necessary to ensure that the recipients have the necessary skills to operate and/or maintain it. This will likely involve delivering structured training to the recipients, which should begin during the operational phase.

\subsubsection{Infrastructure management plans}

Infrastructure management plans and programs will need to be developed to complement the training provided. They will also directly assist in identifying the financial and human resources necessary to maintain any repurposed or new infrastructure handed over.

\section{Conclusion}

Consideration of the social aspects when provisioning for mine closure is becoming a critical component of the closure planning process. It is acknowledged that this is an emerging area with opportunity to develop further guidance. However, it is incumbent on operators to embrace good industry practice in this area in order to maintain the industry's social licence to operate. 


\section{References}

Bainton, NA \& Holcombe, S 2018, The Social Aspects of Mine Closure: A Global Literature Review, Centre for Social Responsibility in Mining, Sustainable Minerals Institute, The University of Queensland, Brisbane.

Department of Mines, Industry Regulation and Safety 2015, Guidelines for Preparing Mine Closure Plans, Perth, http://www.dmp.wa.gov.au/Documents/Environment/ENV-MEB-121.pdf

George Miller, C 2005, Financial Assurance for Mine Closure and Reclamation, International Council on Mining and Metals, London, http://icmm.uat.byng.uk.net/website/publications/pdfs/mine-closure/282.pdf

International Council on Mining and Metals 2006, Guidance Paper Financial Assurance for Mine Closure and Reclamation, London, http://www.icmm.uat.byng.uk.net/website/publications/pdfs/mine-closure/23.pdf

International Council on Mining and Metals 2015, ICMM 10 Principles, London, https://www.icmm.com/en-gb/members/membercommitments/icmm-10-principles

International Council on Mining and Metals 2019, Integrated Mine Closure Good Practice Guide, 2nd Edition, https://www.icmm.com/website/publications/pdfs/closure/190107_good_practice_guide_web.pdf

International Finance Corporation 2012, Performance Standards, Washington DC, https://www.ifc.org/wps/wcm/connect/ Topics_Ext_Content/IFC_External_Corporate_Site/Sustainability-At-IFC/Policies-Standards/Performance-Standards

International Finance Corporation 2007, Environmental Health and Safety Guidelines, Washington DC, https://www.ifc.org/wps/ wcm/connect/topics_ext_content/ifc_external_corporate_site/sustainability-at-ifc/policies-standards/ehs-guidelines

NSW Department of Planning and Environment 2012, ESG1: Rehabilitation Cost Estimate Guidelines, Sydney, https://www.resourcesandgeoscience.nsw.gov.au/_data/assets/pdf_file/0006/363516/PUB17-279-ESG1-RehabilitationCost-Estimate-Guidelines-June-2017.pdf

NSW Department of Planning and Environment 2017, Rehabilitation Cost Estimation Tool Handbook, Sydney, https://www.resourcesandgeoscience.nsw.gov.au/_data/assets/pdf_file/0010/718597/PUB17-282-Rehabilitation-CostEstimation-Tool-Handbook-June-2017.pdf

NSW Trade \& Investment 2013, ESG3: Mining Operations Plan (MOP) Guidelines, Maitland, https://www.resourcesandgeoscience. nsw.gov.au/_data/assets/pdf_file/0009/475434/ESG3-Mining-Operations-Plan-MOP-Guidelines-September-2013.pdf 